\title{
Educational Status of Muslim Women in India: An Overview
}

\author{
FirdausBano \\ Research Scholar KolhanUniversity, Chaibasa, Jamshedpur, India
}

\begin{abstract}
ABSTRA C T: - Women constitute almost half of the population of the world.Education forwomen is the best way to improve the health nutrition and economic status of a household that constitute a micro unit of nation economy.

Gender disparities in education and all other social and demographic indicators reflect the unequal position of girl and women in highly sexist gender discriminatory social order. While historically there has always been a gap between the boys and girls in India, the case of Muslim Women has been yawing.

The Study aimed at giving a brief overview of education status of Muslim women and toexplore the future directions and strategies for integrating and galvanizing women of all walks of lifefor playing their role in building and sustaining the 21st Century. And moreimportantly building an equitable social order and a society that will give its women not only formal equality but a life of dignity.
\end{abstract}

\section{INTRODUCTION}

Education is the single most important tool for social and economic transformation. A well-educated population, adequately equipped with knowledge and skill is not only essential to support economic growth but is also a precondition for growth to be inclusive since it is the educated and skilled person who can stand to benefit most from the employment opportunities which growth will provide.Education is the most important thing for any country. Right to Education Act (RTE Act) gives fair and equal chance to every Indian child to get free and compulsory primary education. Modern studies suggest that female education is more important than male education for social and economic development. "Education is the great engine of personal development. It is through education that the daughter of a peasant can become a doctor, that the son of a mineworker can become the head of the mine, that a child of farmworkers can become the president of a great nation. It is what we make out of what we have, not what we are given, that separates one person from another."

- Nelson Mandela.

Muslims, the largest minority community in the country, constituting $14.23 \%$ of the population,are seriously lagging in terms of most of the human development indicators. Among them Muslim girls and women lagbehind their male counterparts and women of all the other communities.

\section{IMPORTANCE OF WOMEN EDUCATION}

"Education for all" is one of the major tasks being carried out by the Indian government but still we have the lowest female literacy rate in Asia. India is working but the pace is slow as we haven't achieved what we should haveachieved a long time ago.Parents especially in lower strata of society send their male child to school but not the girl child. This is one problem where parents do not send their daughters to school. Secondly, it is also common to see that parents especially in urban areas often send their male child to better schools.

According to Napoleon "Nation's progress is impossible without trained and uneducated mothers. If the women of my country are not educated, about half of the people will be ignorant."Education liberates women from ignorance, increase self-esteem and helps them take control over their own lives and guide the progress of their families.Women are the backbone of a society. They are as equally important as men are. The role of women cannot be denied in any society or culture.

Women must be educated for a healthy and a happy life. An educated woman can be a better human being, successful mother and a responsible citizen. Educating women will unquestionably increase the living standard both at and outside home. An educated woman will force her kids to study further and wish them to live a better life than hers.Napoleon once said, "Give me educated mothers and I will give you educated nations."On the other hand, women are most vulnerable to trafficking when they are under educated and poor, says the United Nations Inter-Agency Project on Human Trafficking (UNIAP).

A woman has to play three roles in the course of her life. Each of these roles expects some duties from her. It is only with the help of education that she would be able to do them successfully. The first duty is to be a good daughter. Second duty is to be a good wife and third duty is to be a good mother. Education teaches a woman what she should do to be good daughter, good wife and a good mother. An educated lady is good friend, a clever nurse and a useful adviser to her husband.

DOI: 10.9790/0837-2206031013 www.iosrjournals.org $\quad 10 \mid$ Page




\section{WHAT ISLAM SAYS}

According Islam said, "A mother's lap is the first school for child.” There is no priority for men over women in relation to the right to education. Both are equally encouraged to acquire education. Indeed, all the Quranic verses which relate to education and which advocate the acquisition of knowledge were directed to both men and women alike.

\section{LITERACY RATE}

It is unanimously agreed that illiteracy is one of the major contributors to poverty in any socio-religious community.

Literacy Rate among Religious Communities: (in \% age)

\begin{tabular}{|l|l|l|l|}
\hline & Female & Male & Total \\
\hline Muslims & 51.9 & 62.41 & 57.155 \\
\hline Hindus & 55.98 & 70.78 & 63.38 \\
\hline Jains & 84.93 & 87.86 & 86.395 \\
\hline Christians & 71.97 & 76.78 & 74.375 \\
\hline Sikh & 63.29 & 71.32 & 67.305 \\
\hline Buddhists & 65.6 & 77.87 & 71.735 \\
\hline Other & 41.38 & 59.38 & 50.38 \\
\hline
\end{tabular}

Source: 2011 census

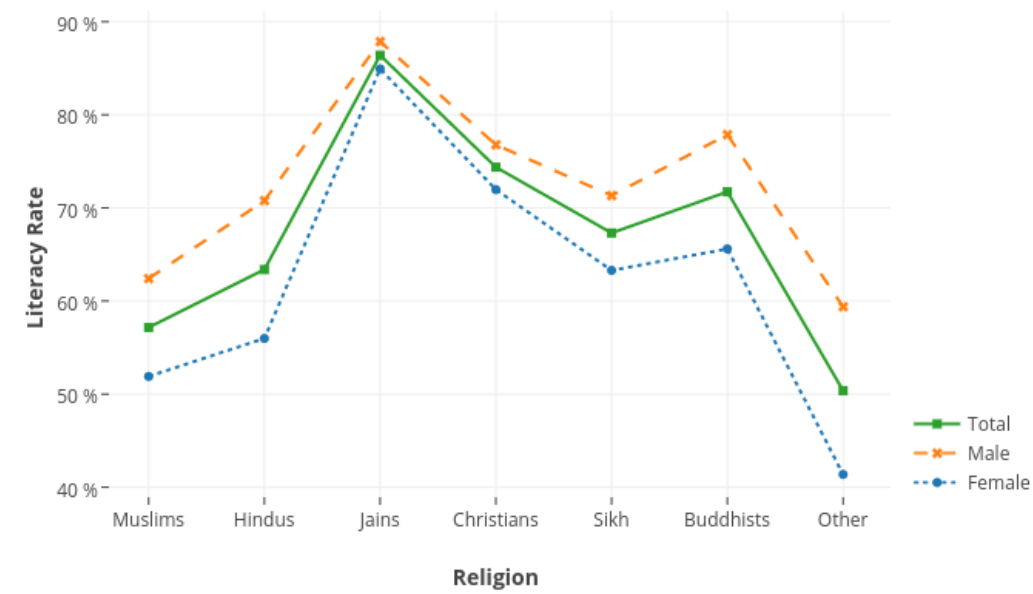

Fig: Literacy Rate among Religious Communities

The above graph shows the literacy rates among the religious communities in India according to the census 2011. It is seen that the literacy rate of Muslim females is only $51.9 \%$ which is lower than all other religiouscommunities and it is even lower than the national average of femalesi.e. $65.46 \%$.

\section{EDUCATIONAL STATUS OF MUSLIM WOMEN IN INDIA}

Educationally Muslim comprise one of the most backward communities in the country. Muslim girls and women lag behind their male counterparts and women of all other communities. Among the Muslims, $17.6 \%$ is the dropout rate, higher than the national average of $13.2 \%$. As many as $25 \%$ of Muslim children in the age group of 6 to 14 years have either never attended school or have dropped out. Muslims have the highest dropout rate in the country. Only one out of the 25 under-graduate students and one out of the 50 postgraduate students is a Muslim in the premier colleges. The share of Muslims in all courses is low. Particularly at the PostGraduate level and marginal in the science stream. (Sachar 2006)

Education is one of the important social indicators having bearing on the achievement and the growth of an individual as well as community. This is apparent to be highly suitable for providing employment and, thereby, improving the quality of life. The educational status of Muslim women in India is worse as compared to Muslim men, and women of other communities. They have the lowest work participation rate and most of them 
engage in the self-employment activities. "The government is still holding on to the survey of Sachar Committee that came out with the data that $66.6 \%$ of Muslim women can read and write. They didn't ask the women what they can read and what they can write. If they had, most women would have said they can read the Quran and they can write some Urdu. The problem is that documents detailing their state entitlement happen to be in English or vernacular languages. So most Muslim women are left in the lurch," Farhat Amin, the Orissa coordinator for the Bharatiya Muslim MahilaAndolan (BMMA)A study done by Zoya Hasan and Ritu Menon highlights important issue related to the status of Muslim women in India. This survey was conducted in 20002001 covering 40 districts in 12 States. Although all women suffer gender based inequalities in marriage, autonomy and mobility across communities, Muslim women fare lower than the national average in certain key areas. These include socioeconomic status, occupational distribution, labour force participation and education. (Hassan and Menon 2004)

The studies byNayer (2007), Hussain (2009) and Jafri (2010) also indicate Muslim women are marked with stark educational backwardness. Many studies and literature have given perspectives on the various reason and issues behind the educational backwardness of Muslim women.

\section{CAUSES OF ILLETERACY}

Following are the most frequent causes of illiteracy:

1. Poor economic condition of the parents.

2. Had to look after their young siblings and old ailing ones.

3. Teaching and learning procedure in the schools are not attractive and effective.

4. Failing to enjoy individual attention of teacher due topoor student-teacher ratio.

5. Interest of the girl's education is subdued by that of marriage at early age.

6. Lack of female teacher in a school.

7. Engaged in wage earning activities to help their parents.

8. Parents are illiterate and ignorant about importance of education of their girl child.

9. Schools are not available within walking distance and closer to the place of dwelling, parents are a bit reluctant due to the feeling of insecurity.

10. Parents also do not see the value of educating daughter who would get married and remain a housewife.

Since they cannot see any direct relationship between education and economic betterment, they have very little motivation to send their girl child to school. The lives of girls and women continue to be controlled by the male-controlled belief systems and structures, which use prescriptions and proscriptions and even naked force to keep women in their place. Men take all decisions and they own all assets.

\section{CONCLUSION AND SUGGESTION}

India is in dire need of policy innovations to include the lower castes, tribal and Muslim people intothe development mainstream. Social inclusion has been attempted through a policy of reservation, which has failed to uplift the minorities. Though many steps have been taken so far to improve the education level of women in India but the 86th Constitutional Amendment Act, 2002 has been a commendable step in this regard. Under this act elementary education was made free and compulsory for the children belonging to the age group of 6-14 years. This initiated SarvaShikshaAbhiyan (SSA). SSA is the main programme to achieve Universalization of Elementary Education (UEE) in a time bound manner.Currently, there is underutilization of funds, unmet targets and delays in completion of public sector projects compounded by corruption.This paper calls for assessments of social development in various states to see why thedisparity has narrowed in some states but not in others. Socioeconomic backwardness an indicators thereof should be organized properly and considered before framing educational policy orproviding subsidy, rather than basing it on religion. This would enhance the overalldevelopment effort currently gaining momentum in the country.

\section{REFERENCES}

[1] Ansari I.A (1988) "Muslim Educational Backwardness: New Educational Policy and Programme", The Muslim Situation in India, New Delhi: Sterling Publishers.

[2] Ahmad, A. Muslims in India (Vol.1). New Delhi: Inter India Publications, 1991.

[3] Durrani F.K.K. A plan of Muslim educational Reform. Lahore: Nawar Printing Press, 1989.

[4] S.Ruhela, S.P. (1998) "Religion, Social Class and Educational Opportunity: Case Studies of Eight Muslim Girls".

[5] Ruhela, S.P. (Ed.). (1998). Empowerment of the Indian Muslim Women, New Delhi, MD Publications.

[6] Siddiqui,Z., and Zuberi, A., (Ed.), Muslim women: Problems and Prospects, New Delhi,MD publications, 1993.

[7] Khalid, O. Indian Muslims since Independence. New Delhi: Vikas Publishing House, 1994. 
[8] Ahmed, I., (1980) The Problem of Muslim Educational Backwardness in Contemporary India: An Inferential Analysis, Occasional paper.

[9] Hamid, S., (1985) "Educational Status of Indian Muslims” Muslim India, December 1985.

[10] Nasreen (2013) Education of Muslim Women, A journey from past to present, International Journal of Management and Social Sciences, Research volume 2, No.1.

[11] NarulaM. (2012). Women Education and Policies of Inclusion: In Post-Independence India. In S. Akhilesh (Ed.), Indian society: Issues and Problems, Madhya Pradesh, India: Gayatri Publications.

[12] Minault, G. (1982). Purdah Progress: The Beginnings of Social Education for Indian Muslim women in JP Sharma (Ed.), Individuals and Ideas in Modern India (pp. 76-97) Calcutta India Firma K.L.M.

[13] Nuna, A. (2003) Programmes and schemes for education of minorities: Evolution of Area Intensive Scheme. In A. Waheed (Ed.), Minority Education in India: Issues of Access, Equity and Inclusion (pp. 75-85). New Delhi, India: Serial Publications.

[14] UshaNayar "An Analytical Study of Education of Muslim Women and Girls in India" (Ministry of Women and Child Development) New Delhi 2007. 